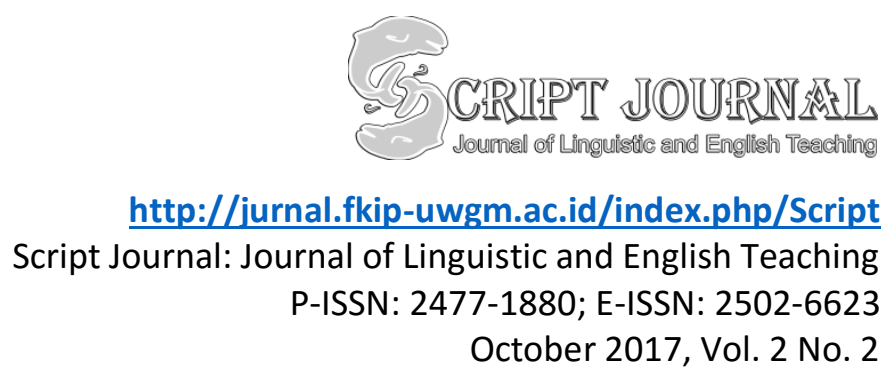

\begin{tabular}{|l|l||c|} 
Received: September 2017 & Accepted: September 2017 & Published: October 2017
\end{tabular}

Article DOI: http://dx.doi.org/10.24903/sj.v2i2.134

\title{
A Revisit of the Gricean Maxims in Manado Malay Language
}

\author{
Stevanus Ngenget \\ Universitas Katolik De La Salle \\ sngenget@unikadelasalle.ac.id
}

\begin{abstract}
Some researchers have tried to challenge the dominance of Gricean maxims in terms of its consistency. One way oftesting itis by conducting research in vernacular language. This research is therefore conducted to revisit Gricean maxims in Manado Malay language, a language used by the people who live in Manado and its surroundings. This research, therefore, aims to find out (1) how the Cooperative Principle is violated in Manado Malay language, and (2) what the purpose of the generated implicatures are. The data used for analysis in this research were taken from recorded lunch break conversation of the lecturers at Unika De La Salle Manado in July 2016. The result showed that the Gricean maxims: maxim of quantity, maxim of quality, maxim of relation and maxim of manner were observed in Manado Malay language. It was also found that implicatures generated in Manado Malay language were meant for giving information. It can be concluded that Gricean maxims are consistent when implicatures occur in Manado Malay language. Furthermore, speakers of Manado Malay language usually produce implicature to give information and to joke.

Keywords: Gricean maxims, Cooperative Principle, Implicature
\end{abstract}




\section{INTRODUCTION}

The underlying principle of Grice, (1975) theory is that human interaction has a potential for misinterpretation because there are utterances that cannot be interpreted merely by looking at the words that compose the utterances (Åkerman, 2009). It would be too naïve to look at the words themselves to understand what people try to convey in conversation (Bezuidenhout \& Cutting, 2002). It is true that semantic meaning where the grammar, structure and vocabulary play a role in shaping the meaning of certain sentences, however, pragmatic meaning also exist and play an important role especially in communication(P Dekker, 2002: Capone, 2006). Grice, (1975) is well aware of this. Therefore, he puts forward his Cooperative Principle theory. According to Grice, a good conversation should observe the four maxims known as the Gricean maxims which are maxim of quantity, maxim of quality, maxim of relation and maxim of manner. When one or more of these maxims are violated, in other words when the Cooperative Principle is defied, the meaning should be interpreted. The interpretation could be so alienated from the words that compose the utterance which he refers to as implicature. Maxim of quantity refers to the information given during conversation. The principle is that information should be as informative as required, not more or less. Maxim of quality refers to the information which is true. Maxim of relation refers to the information which should be relevant and maxim of manner talks about avoiding ambiguity in utterances.

There have been researches conducted to analyze how implied meaning takes place in conversation. In her research, Brumark (2006) finds that implied meaning is observable when people communicate in the family dinner table. In other research, Fetzer, (2006) observes that in political conversation, implicature is used to avoid the topic a speaker is not comfortable with. Moreover, implicature is also observable in textual research such as in S Chapman, (2012) where he studies about implicature in detective novels, and S. Ngenget, (2007) where he researches the violation of Gricean maxims in Harold Pinter's novel, The Birthday Party. Grice's theory has even been researched further such as in C Jagoe, (2015) where she finds that implicature is observable in mentally disabled informants.

While Grice's Cooperative Principle has been researched across countries and languages, researches on vernacular language or language used by ethnic groups need to be addressed more. In Indonesia, for example, there are over 300 languages used by certain group, ethnic or race for communication (Sandjaja, n.d.), an ample opportunity for language researches. In this research, therefore, Grice's theory on implicature is implemented on the language used by thegroup of people who live in Manado and its surroundings called Manado 
Malay Language (Salea-Warouw, 1981). Specifically, this research aims to address the following questions: (1) how is the Cooperative Principle violated in Manado Malay language? And what is the purpose of the implicature generated?

\section{METHODOLOGY}

The nature of this research is qualitative. Therefore, the data collection and analysis used qualitative approach. To be specific, the method used in this research was descriptive qualitative which emphasized on the process and meaning based on the social reality where the research was conducted, putting aside typical components of quantitative research such as size and frequency (Denzin \& Lincoln, 2009), (Arbain, 2016) (Nur, 2017).

Research data were taken from conversation among colleagues of De La Salle University during lunch break. The subjects were chosen based on convenience, as it was easier to spot the subjects during lunch break because they usually sat in a gazebo for lunch. Besides, during the break the language used by the subjects was Manado Malay language which was the focus of this research. Another thing was that open conversation was expected during the lunch break, as the subjects have known each other for years.

For data collection, researcher used cellphone application called Audio Notes to record the conversation. This instrument was chosen because it allowed the researcher not only to record the data but also to make notes in the application when necessary. Besides, the quality of the recording by using this application was better than other build-in application in the cellphone.

Lunch break at De La Salle University starts from 12.00 to 13.00. During this time, the employees usually gather at the gazebo for lunch. This was the time when the recording took place. The recording was simply started by pressing the recording button on the screen. After the lunch break was over for about one hour, pressing the toggle button stopped the recording. This procedure carried on for one month in August 2016. The recording took place without prior notice of the subjects. It was purposively implemented to avoid Hawthorne Effect where the participants behave unnaturally realizing that they are being research (Back, 2013:Haghverdi, 2010). However, when the data collection finished, the subjects were told about the recording.

The first phase of data analysis started with separating the utterances that violated the Gricean maxims from the rest. The utterances called implicatures were then separated based on the maxims violated whether it was maxim of quantity, maxim of quality, maxim of 
relation, or maxim of manner. After the violation of each maxim was identified, the purpose of each utterance was calculated(L Baptista, 2011:Chien, 2008).

\section{FINDINGS}

\section{Violation of the Gricean Maxims}

While the emergence of Neo-Gricean (A Caink \& Clark, 2012:Levinson, 1991) and Post-Gricean theories (Burt, 2002) tries to compete with the existing Gricean theory, it is apparent from the research that the violation of Gricean maxims is observable in Manado Malay language. It means that Cooperative Principle is defied due to violation of the four maxims Grice proposes: maxim of quantity, maxim of quality, maxim of relation and maxim of manner. This indicates that the users of Manado Malay language have a tendency to use implicature in their daily lives. Evidence of the violation of each Gricean maxim which then triggers implicature is described below.

\section{Maxim of Quantity}

As stated earlier, the violation of maxim of quantity in conversation relates to the quantity of information provided. When an utterance is not as informative as required, the violation occurs like what can be observed in Example 1 below. From this Example 1 forward, the utterance will be put in three lines. The first line is the original utterance in Manado Malay language, the second line is the translation by words, and the last line is the free interpretation or translation of the wholeutterance.

Example 1:

Speaker A: Bro, mo ba gabung acara sabantar malam?

Brother, want to join party later tonight?

'Brother, do you want to join the party tonight?'

Speaker B: Suka mo pigi mar kapala so saki ini.

Like to go but head begin feel pain now.

'I would like to, but I have just had my headache.'

The utterance produced by Speaker B is an implicature as the result of violation of the maxim of quantity. The reason why Speaker B's utterance violates the maxim of quantity because Speaker A's question only requires a 'yes/no/ answer. However, Speaker B says that he has a headache. As Speaker B does not give sufficient information as required, he violates the maxim of quantity. It is important to note that even though it looks like Speaker B does not respond to Speaker A's question, in fact, by saying he has a headache, Speaker B sends message to Speaker A that he cannot join the party. 


\section{Maxim of Quality}

Violation of the maxim of quality occurs when an utterance does not reflect truth. From the example below, it is apparent that implicature as the result of violation of the maxim of quality is also observable in Manado Malay language.

Example 2:

Speaker A: Ngana pe milu di rumah masih ada?

Your corn at home still have?

'Do you still have corn at home?'

Speaker B: Napa masih da satu gunung.

(Particle) still have one mountain.

'I still have a mountain of it.'

This conversation consists of a violation of the maxim of quality especially in Speaker B's utterance. It is understandable from the conversation that Speaker A only asks Speaker B whether he still has corn at home, however, Speaker B responses by saying he still has a mountain of corn. It is obvious that Speaker B does not give true information because a size of a mountain for corn does not seem to be factual. However, it does not mean that Speaker B's statement is meaningless. By violating the maxim of quality, he tries to communicate to his interlocutor that he still has corn at his home.

\section{Maxim of Relation}

There is also evidence of the violation of maxim of relation in the research because the speaker gives response that is not relevant to what his counterpart says. The conversation can be seen in Example 3 below.

Example 3:

Speaker A: Na tau berapa surat satu kali kita kirim waktu SMA?18.

You know how many letters one time I send when High School? 18.

'Do you know how many letters one time I sent during high school?' 18

Speaker B: Pantas na pe rambu capat abis.

No wonder your hair quick gone.

'No wonder you get bald so quickly.'

Speaker B's statement violates the maxim of relation because there is no relation between sending letter and getting bald. Even though, Speaker B's utterance seems to be irrelevant, however, there is a real meaninghe wants to convey. It is obvious that he wants to joke by saying that Speaker A's baldness is due to a number of letters he sent during high school. 


\section{Maxim of Manner}

The violation of the maxim of manner on the other hand refers to the clarity of an utterance produced. When an utterance is ambiguousor does not have a clear meaning, it violates the Cooperative Principle in this case by violating the maxim of manner. Occurrence of the violation of the maxim of manner in Manado Malay language can be seen in the following example.

Example 4:

Speaker A: Ngoni da lia pa WR2?

Youhave seen Vice Rector for Financial Affair?

'Have you seen the Vice Rector for Financial Affair?'

Speaker B: Tadi dia bilang dari Rumah Saki kong kamari.

Some times ago he said from Hospital and here.

'Some times ago he told me that he just came from the hospital.'

It is clear from Speaker A's question that he simply asks for a 'yes/no' answer. However, Speaker B responds in different way. In this case, Speaker B's utterance violate the maxim of manner because it creates confusion to Speaker A. Speaker A might get confused why the Vice Rector came from the hospital. He might think that the Vice Rector is sick or he just visits someone who is sick. However, it does not mean that Speaker B does not try to convey a meaning in his utterance. He wants to say that the Vice Rector is in fact in campus now because he has met him.

From the examples above, it is clear that Cooperative Principle in Manado Malay language is violated in terms of Gricean maxims. When implicatures observed, they occur due to violation of the maxim of quantity, maxim of quality, maxim of relation and/or maxim of manner.

\section{Purpose of the Implicature Generated}

Looking at the examples above, it can be observed that implicatures are usually generated as a response to a question asked by the interlocutor. Therefore, the purpose of implicature generated in Manado Malay language is mostly for giving information. If we look at Example 1, it is obvious that Speaker A asks about information whether or not Speaker B wants to join the party. In Example 2, Speaker A also wants to know whether Speaker A still has corn at his home. The same case is applicable in Example 3 and Example for. From these occurrences, it can be assumed that implicatures in Manado Malay language are usually generated for giving information. 
There are also examples from the data showing people use implicatures to joke. Evidence of violation of the Cooperative Principle for joking can be seen in Example 3. In this example, Speaker B talks about Speaker A's head. Speaker B jokes about Speaker A's baldness due to his habit of sending to many letters for correspondence during high school. Even though the statement sounds sarcastic but joking has become part of the way of life of the people who use Manado Malay language for communication.

\section{DISCUSSION}

After Grice,(1975) proposes his theory known as the Gricean maxims, linguists and researchers try to prove that his theory is a flaw. Researchers argue that it is impossible that Cooperative Principle is generated from only from the violation of the maxim of quantity, maxim of quality, maxim of relation or maxim of manner. It does not seem to be adequate considering that language is a very complex thing. Language inventory is so various that it has so many features, if not unlimited, and these features exist in any languages used by human being.

Due to their skepticism, researchers try to investigate and challange the Gricean maxims. While some researchers try to bring in new theory to challange Grice's theory, it is remarkable that many researches have also proved that Gricean maxims still stand out amids the challanging propositions. What makes it more interesting is that Gricean maxims have been studied in more than one language and most of the results are in favor of the Gricean maxims.

This study is one example of how Gricean maxims are put to test in a vernacular language. From the earlier discussion it is apparent that Gricean maxims are observable when generated implicatures are studied in Manado Malay language. Even though Grice's theory is evident in this research, there are some points which is worth considering in this research which are the role of the context and the importance of intimacy of the speakers involved in the conversation.

\section{The Role of Context}

As suggested by most researchers (M Blome-Tillmann, 2013:Lewis, 2012), context plays a central part in generating the meaning of implicatures as what is observable in this research.Discussion on how context plays a role in understanding implicatures will be conferred based onL Song, (2010) proposition. In his scheme, Song classifies context into three which areLinguistic Context, Situational Context, and Cultural Context. Following is the discussion of each of the context. 


\section{Linguistic Context}

Linguistic context refers merely to the words and sentences used in utterances. For example, when someone says:

"My father is a doctor."

This utterance simply indicates that the speaker's father has an occupation as a doctor. This understanding comes from the words composing the utterance themselves. In other words, people can understanding the meaning of this utterance simply by translating the words composing the sentence literally.

\section{Situational Context}

On the other hand, Situational Context refers to environment, time and place where an utterance occurs. For example, when someone says:

"I'm so hungry. Do you have some rice?"

In understanding this statement, interlocutor needs to involve deeper understanding as the meaning of the utterance includesoption because the word 'rice' may refer to the cooked rice and uncooked rice. However, it is clear fromthe situational context that the speaker wants a cooked rice to eat, not the uncooked rice.

\section{Cultural Context}

Cultural Context refers to culture and customs of the language users. This context is observable in the husband's replyto the wife'squestion about when the husband comes back home below:

"Same time as usual."

The husband's reply even though it is not clearly stated, but it is understandable perfectly to the wife.This reply indicates that the husband will come back as the same time as the wife knows. It is because the wife and the husband share the same family custom. The custom is built as they have been together for some times in a marriage.

In this research, the role of context can also be identified. In Example 4, Speaker A asks his counterpart whether he has seen the Vice Rector for Financial Affair. Without hesitating, Speaker B responds by indicating that he has met and talked to him. Speaker B knows for sure that Speaker A refers to their Vice Rector of Financial Affair, not vice rector of other schools because the speakers share the same cultural context. They work in the same institution. Therefore, when one of the speakers mentions about the Vice Rector, the other speaker understands from his cultural background that his interlocutor must be talking about their Vice Rector.Moreover, Speaker A's utterance also in reference to linguistic context as the meaning of the utterance must be referred to the word components forming the sentence. 


\section{Intimacy between the Speakers}

It is true that context plays a central part in the generation of implicature. However, it is insufficient to consider that context is the only important component that defines implicature. While researchers have not paid much attention on intimacy, in Manado Malay language itself, intimacy is very crucial in conversation. The importance of intimacy can be seen in Example 3. In this example, Speaker A asks Speaker B whether he knows how many letters Speaker A sent one time. When Speaker B finds out that there are so many letters Speaker A sent, Speaker B says that it is the reason why he gets bald so quickly. It is obvious that Speaker B's utterance sounds sarcastic.

However, Speaker A does not get offended by Speaker B's statement. It might look unacceptable to other people, however, considering the close relationship between Speaker A and Speaker B as colleagues, Speaker B's utterance does not affect Speaker A. This case might result in different outcomes when Speaker A and Speaker B do not have intimate relationship.

\section{CONCLUSION}

This research shows that the users of Manado Malay language is familiar with implicatures in conversation. They generally use implicatures in their daily conversations. Implicatures generated in the conversation are the results of violation of the Gricean maxims: maxim of quantity, maxim of quality, maxim of relation, and maxim of manner. In most cases, implicatures are generated because the speakers want to give information to his interlocutors. There are also evidence where the users of Manado Malay language generate implicature to joke.

\section{BIBLIOGRAPHY}

Åkerman, J. (2009). A plea for pragmatics. Synthese, 170((1)), 155-167.

Arbain, A. (2016). Critical Discourse Analysis of Eminem 's " Love the Way You Lie Part II ." Script Journal, 1(1), 1-10. https://doi.org/10.24903/sj.v1i1.19.g8

Back, M. (2013). Using Facebook Data to Analyze Learner Interaction During Study Abroad. Foreign Language Annals, 46(3), 377-401. https://doi.org/10.1111/flan.12036

Baptista, L. (2011). Say What? On Grice On What Is Said. European Journal of Philosophy, $22((1)), 1-19$.

Bezuidenhout, A., \& Cutting, J. C. (2002). Literal meaning, minimal propositions, and pragmatic processing. Journal of Pragmatics, 34, 433-456.

Blome-Tillmann, M. (2013). Knowledge and implicatures. Synthese, 190(18)((18)), 42934319.

Brumark, A. (2006). Non-observance of Gricean maxims in family dinner table conversation. 
Journal of Pragmatics, 38, 1206-1238. https://doi.org/10.1016/j.pragma.2005.03.014

Burt, S. M. (2002). Maxim confluence. Journal of Pragmatics, 34, 993-1001.

Caink, A., \& Clark, B. (2012). Special Issue on Inference and Implicature in Literary Interpretation. Journal of Literary Semantics, 41((2)), 99-103.

Capone, A. (2006). On Grice's circle (a theory-internal problem in linguistic theories of the Gricean type). Journal of Pragmatics, 38, 645-669. https://doi.org/10.1016/j.pragma.2006.02.005

Chapman, S. (2012). Towards a Neo-Gricean Stylistics: Implicature in Dorothy L. Sayers's Gaudy Night. Journal of Literary Semantics, 41((2)), 139-153.

Chien, A. (2008). Scalar implicature and contrastive explanation. Synthese, 161, 47-66.

Dekker, P. (2002). Pronouns in a pragmatic semantics. Journal of Pragmatics, 34, 815-827.

Denzin, N. K., \& Lincoln, Y. S. (2009). Handbook of Qualitative Research. California: Sage Publication.

Fetzer, A. (2006). "“Minister, we will see how the public judges you."” Media references in political interviews. Journal of Pragmatics, 38, 180-195. https://doi.org/10.1016/j.pragma.2005.06.017

Grice, H. P. (1975a). Logic and Conversation. In Syntax and semantics 3: Speech arts (pp. 41-58). Academic Press.

Grice, H. P. (1975b). Logic and Conversation. In Syntax and semantics 3 Speech arts. Academic Press., pp. 41-58.

Haghverdi, H. R. (2010). The Effect of ote-taking Strategy Instruction on the Students. Academic Achievement, 7((2)), 123-151.

Jagoe, C. (2015). Collaborative meaning-making in delusional talk as a search for mutual manifestness: A Relevance Theory appro ach. Journal of Interactional Research in Communication Disorders, 6((1)), 53-71.

Levinson, S. C. (1991). Pragmatic reduction of the binding conditions revisited. Journal of Linguistics, 27, 107-161.

Lewis, K. S. (2012). Discourse dynamics, pragmatics, and indefinites. Philos Stud, 158, 313342.

Ngenget, S. (2007). An analysis of the flouting of Gricean maxims in Harold Pinter's The Birthday Party. Nanyang Technological University.

Nur, D. R. (2017). An Analysis of the Feminist Characters in Kate Chopin's "The Awakening." Journal of English Educators Society, 2(April), 1-20. https://doi.org/10.21070/jees.v2i1.687

Salea-Warouw, M. (1981). Variasi Bahasa Manado. Jakarta.

Sandjaja, D. P. (n.d.). Indonesian | Asian Languages \& Literature | University of Washington.

Song, L. (2010). The Role of Context in Discourse Analysis. Journal of Language Teaching and Research, 1((6)), 876-879. 